\title{
Analisis Risiko Usahatani Salak Organik di Desa Sibetan Kecamatan Bebandem Kabupaten Karangasem
}

\author{
I GUSTI AYU AGUNG DEWI MAHAYANI, I KETUT BUDI SUSRUSA, \\ I WAYAN BUDIASA
}

\author{
Program Studi Agribisnis, Fakultas Pertanian, Universitas Udayana \\ Jalan PB Sudirman Denpasar 80232 \\ Email: gungdeka1705@gmail.com \\ kbsusrusa@yahoo.co.id
}

\begin{abstract}
The Risk Analysis of Zallaca Organic Farming in Sibetan Village Subdistrict Bebandem Karangasem Regency
\end{abstract}

Sibetan village is a development center of zallaca organic farming in subdistrict Bebandem, Karangasem regency. The problems that have been faced by zallaca organic farming like a fluctuation of production and commodity prices, thus indicating the risk that must be faced by the farmers related to production and the selling price of the commodity in the market. If production and price has a risk, it will affect to the farmers income. This study aimed to analyze factors that affect the income of farmers in zalacca organic farming, analyze the production risk, price risk and income with a risk. The research method used quantitative analysis.

The result showed the factors that affect the farmers income of zallaca organic farming in Sibetan Village are the land area. The research shows the average farming costs incurred by $\mathrm{Rp} 2.784 .050,78$ farming per hectare, while the average total revenue obtained by $\mathrm{Rp} 9.493 .215,20$ per hectare, thus obtained the average income of zallaca organic by Rp 6.709.164,27 per hectare. The coefficient variation in production is 0,50 which means the production of zalacca organic in Sibetan village has a low risk, the value of the coefficient variation in price is 0,11 , which means the price or organic zallaca commodity in Sibetan village has a low risk, and the coefficient variation income is 0,55 means that farm income zalacca organic at Sibetan village has a low risk.

Keywords: zallaca organic farming, risk, coefficient variation

\section{Pendahuluan}

\subsection{Latar Belakang}

Pertanian memegang peranan penting dalam kehidupan ekonomi di negaranegara berkembang, demikian pula di Indonesia (Widodo, 2008). Sektor pertanian terdiri dari subsektor tanaman pangan, subsektor perkebunan, subsektor peternakan dan subsektor hortikultura. Subsektor hortikultura terdiri atas komoditas buahbuahan, sayuran, tanaman hias dan tanaman obat-obatan (Dewi, 2006). Salah satu alternatif pilihan komoditas buah-buahan yang dikembangkan oleh pemerintah 
adalah salak. Salak merupakan salah satu jenis buah tropis di Indonesia dan menjadi komoditas unggulan nasional.

Provinsi Bali memiliki sentra pengembangan komoditas salak yang menerapkan teknologi budidaya organik yang terdapat di Desa Sibetan Kecamatan Bebandem Kabupaten Karangasem. Dinas Pertanian Tanaman Pangan dan Hortikultura Kabupaten Karangasem (2016) menyebutkan Kecamatan Bebandem merupakan penyumbang produksi salak terbesar di Kabupaten Karangasem yaitu $45,52 \%$. Usahatani salak organik umumnya mengalami beberapa kendala yang berpotensi menjadi risiko. Risiko usahatani yang dihadapi oleh petani salak organik dapat dilihat berdasarkan produksi per tahun-nya (2011-2015) di Kecamatan Bebandem sebagai berikut.

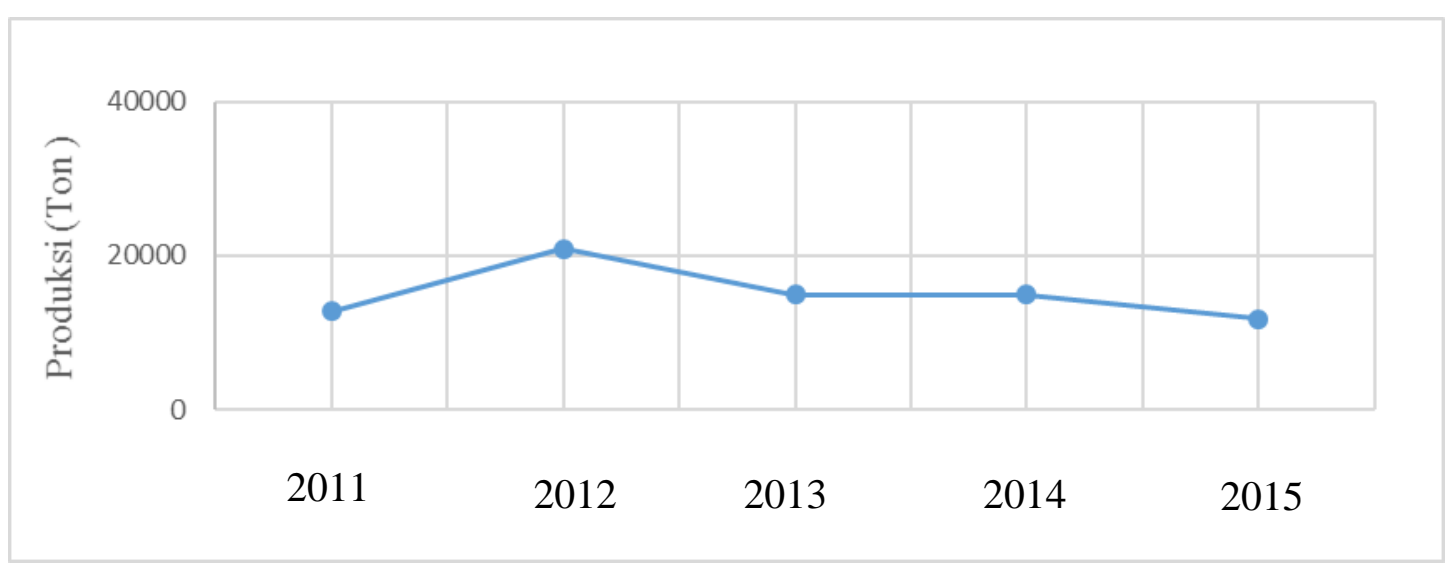

Gambar 1. Perkembangan Data Produksi Salak Organik di Kecamatan Bebandem Kabupaten Karangasem Tahun 2011-2015

Berdasarkan gambar 1 menunjukkan bahwa Desa Sibetan mengalami fluktuasi produksi tiap tahunnya. Hasil produksi yang mengalami peningkatan dan penurunan menyebabkan harga komoditas di pasar berfluktuasi. Kondisi ini tentunya dipengaruhi oleh beberapa faktor yang nantinya akan terkait dengan perolehan pendapatan petani sekaligus risiko yang harus ditanggung.

Tujuan penelitian ini adalah untuk menganalisis faktor-faktor yang mempengaruhi pendapatan petani dalam usahatani salak organik, menganalisis tingkat risiko produksi, tingkat risiko harga dan tingkat risiko pendapatan usahatani salak organik di Desa Sibetan Kecamatan Bebandem Kabupaten Karangasem.

\section{Metode Penelitian}

\subsection{Lokasi dan Waktu Penelitian}

Penelitian dilaksanakan di Desa Sibetan Kecamatan Bebandem Kabupaten Karangasem. Pemilihan lokasi penelitian ditentukan secara purposive (sengaja) dengan pertimbangan Desa Sibetan merupakan sentra pengembangan salak organik di Kabupaten Karangasem. Alasan lain adalah terjadi permasalahann dari fluktuasi produksi, ketidakpastian harga sehingga berdampak terhadap pendapatan petani dan 
menimbulkan risiko pada usahatani salak organik di Desa Sibetan. Waktu penelitian dilaksanakan pada bulan Desember 2016 s.d. Januari 2017.

\subsection{Data, Sampel Penelitian dan Analisis Data}

Data kuantitatif yang dicari pada penelitian ini adalah data panen raya salak organik pada tahun 2016 meliputi jumlah produksi salak organik yang dihasilkan di Desa Sibetan, harga komoditas salak organik, biaya input usahatani yang terdiri dari biaya variabel dan biaya tetap. Biaya variabel terdiri atas pengeluaran biaya untuk pupuk organik, biaya upacara, dan upah tenaga kerja, sedangkan biaya tetap terdiri atas pajak bumi dan bangunan serta penyusutan peralatan usahatani. Data kualitatif yang dicari pada penelitian ini meliputi gambaran umum Desa Sibetan.

Populasi petani salak organik di Desa Sibetan yaitu 118 orang. Berdasarkan rumus Slovin dengan tingkat kesalahan 10\% diperoleh besarnya sampel sebanyak 54 responden petani. Teknik sampling yang digunakan adalah Proportional Random Sampling. Pengambilan sampel secara proporsi dilakukan dengan mengambil subyek dari setiap kelompok tani ditentukan seimbang dengan banyaknya subyek dalam masing-masing kelompok tani (Sugiyono, 2007). Adapun jumlah sampel untuk masing-masing kelompok tani salak organik terbagi atas Kelompok Tani Dukuh Lestari 18 orang, Kelompok Tani Mekar Sari 13 orang, Kelompok Tani Kertha Semaya 16 orang dan Kelompok Tani Werdhi Guna tujuh orang. Pengambilan sampel per tiap kelompok tani ditentukan dengan metode sistem random sampling.

Metode analisis pada penelitian ini menggunakan analisis kuantitatif. Faktorfaktor yang mempengaruhi pendapatan usahatani salak organik dapat dianalisis melalui metode OLS (Ordinary Least Square). Tahapan pertama pertama yang dilakukan adalah mencari nilai pendapatan usahatani salak organik. Menurut Soekartawi (1986) dalam menaksir pendapatan semua komponen produk yang tidak dijual harus dinilai berdasarkan harga pasar. Tenaya (2015) menyebutkan pendugaan fungsi pendapatan dengan kuadrat terkecil biasa (OLS) terkadang ditemui adanya masalah multikolinieritas, sehingga dilakukan uji asumsi klasik. Menganalisis seberapa besar tingkat risiko produksi, harga, dan pendapatan dengan mencari nilai probabilitas setiap kondisi yaitu rendah, sedang, dan tinggi Darmawi (2004). Selanjutnya mencari nilai harapan (ekspektasi), varian, simpangan baku, dan koefisien variasi (Salvatore, 2003). Kriteria yang dipakai dalam penelitian ini adalah apabila nilai koefisien variasi (KV) kurang dari sama dengan satu, maka usahatani yang dianalisis memiliki risiko kecil dan sebaliknya jika nilai koefisien variasi (KV) lebih dari satu, maka usahatani yang dianalisis memiliki risiko besar (Fauziyah, 2011).

\section{Hasil dan Pembahasan}

\subsection{Faktor-faktor yang Mempengaruhi Pendapatan Usahatani Salak Organik}

Berikut ini uraian faktor-faktor yang mempengaruhi pendapatan petani dalam usahatani salak organik, namun sebelumnya dilakukan analisis pendapatan untuk 
mengetahui besarnya pendapatan yang diperoleh petani dari usahatani salak organik di Desa Sibetan.

Tabel 1.

Analisis Rata-rata Penerimaan, Biaya Usahatani, dan Pendapatan Usahatani Salak

Organik di Desa Sibetan Kecamatan Bebandem Kabupaten Karangasem

Tahun 2016

\begin{tabular}{lc}
\hline \multicolumn{1}{c}{ Komponen } & Nilai (Rp) \\
\hline A. Jumlah total penerimaan & $9.493 .215,20$ \\
\hline B. Biaya variabel & \\
1. Sarana Produksi & $310.777,78$ \\
a. Pupuk organik & $1.624 .777,78$ \\
b. Tenaga Kerja & $317.592,59$ \\
c. Biaya Upacara (Rp) & $2.253 .148,15$ \\
Total biaya variabel & \\
C. Biaya tetap & $203.944,44$ \\
a. Pajak & $326.958,33$ \\
b. Biaya penyusutan & $530.902,78$ \\
\hline Total biaya tetap & $2.784 .050,93$ \\
\hline Total biaya usahatani $(B+C)$ & $6.709 .164,27$ \\
\hline Pendapatan usahatani & \\
\hline
\end{tabular}

Sumber : Analisis data primer, 2017

Besarnya penggunaan input produksi tentunya akan berpengaruh terhadap biaya yang akan dikeluarkan untuk pembelian input tersebut. Biaya pengeluaran usahatani merupakan penjumlahan dari biaya variabel dengan biaya tetap, sedangkan penerimaan merupakan hasil kali jumlah produksi dengan harga komoditas. Hasil analisis pendapatan diperoleh dari selisih penerimaan dengan biaya usahatani, maka besarnya rata-rata pendapatan petani salak organik di Desa Sibetan pada panen raya per hektar tahun 2016 sebesar Rp 6.709.164,27.

Analisis faktor-faktor yang mempengaruhi pendapatan petani dalam usahatani salak organik dilakukan terlebih dahulu dengan melakukan transformasi ke dalam bentuk Ln dan melakukan beberapa uji asumsi klasik. Menurut Gujarati dalam Maya (2006), asumsi-asumsi yang harus dipenuhi dalam pendugaan fungsi pendapatan dengan metode kuadrat terkecil (OLS) adalah : 1) variasi unsur sisaan menyebar normal, 2) tidak ada heterokedasitas, 3) tidak ada autokorelasi, dan 4) tidak ada korelasi ganda diantara variabel-variabel peubah bebas (multikolinieritas), sehingga sebelum melakukan uji statistik maka dilakukanlah pengujian terhadap asumsi klasik. Dari analisis yang telah dilakukan diperoleh hasil yang dapat dilihat pada tabel 2 berikut : 
Tabel 2.

Faktor-faktor yang Mempengaruhi Pendapatan Usahatani Salak Organik di Desa

Sibetan Kecamatan Bebandem Kabupaten Karangasem

\begin{tabular}{|c|c|c|c|c|c|c|}
\hline \multirow{2}{*}{\multicolumn{2}{|c|}{ Model }} & \multicolumn{2}{|c|}{$\begin{array}{c}\text { Unstandardized } \\
\text { Coefficients }\end{array}$} & \multirow{2}{*}{$\begin{array}{c}\text { Standardized } \\
\text { Coefficients } \\
\text { Beta }\end{array}$} & \multirow[b]{2}{*}{$\mathrm{T}$} & \multirow[b]{2}{*}{ Sig. } \\
\hline & & $\mathrm{B}$ & Std. Error & & & \\
\hline \multirow[t]{8}{*}{1} & (Constant) & 16,025 & 1,681 & & 9,536 & .000 \\
\hline & Luas Lahan & 0,848 & 0,085 & 0,901 & 9,974 & .000 \\
\hline & Umur Tanaman & $-0,193$ & 0,168 & $-0,069$ & -1.150 & .256 \\
\hline & Tenaga Kerja & -0.012 & 0,100 & $-0,011$ & $-0,121$ & .904 \\
\hline & Pengalaman Usahatani & 0,262 & 0,138 & 0,115 & 1,906 & .063 \\
\hline & R-squared & 0,826 & & & & \\
\hline & Adjusted r-Square & 0,812 & & & & \\
\hline & F-Statistics & 58,217 & & & & \\
\hline
\end{tabular}

Sumber : Analisis data primer, 2017

Nilai $\mathrm{R}^{2}$ adalah 0,826 yang berarti sebanyak $82,6 \%$ variasi dari pendapatan usahatani salak organik dapat dijelaskan oleh variasi variabel independen dalam model, dengan kata lain $82,6 \%$ variabel independen secara bersama-sama berpengaruh terhadap pendapatan petani dalam usahatani salak organik dan sisanya 17,4\% dipengaruhi oleh variabel lain yang tidak diteliti yang merupakan variabel lain di luar model. Nilai F-hitung sebesar 58,217 lebih besar dari $\mathrm{F}$ tabel sebesar 2.008559112 dengan $\alpha=5 \%$ artinya variabel independen secara bersama-sama berpengaruh nyata terhadap pendapatan petani dalam usahatani salak organik.

Hasil uji t menunjukkan bahwa variabel yang berpengaruh nyata terhadap pendapatan petani dalam usahatani salak organik adalah luas lahan. Nilai koefisien dari variabel luas lahan adalah positif artinya semakin tinggi penggunaan faktor tersebut maka pendapatan yang diperoleh petani akan semakin tinggi.

\subsection{Risiko Usahatani Salak Organik di Desa Sibetan Kecamatan Bebandem Kabupaten Karangasem}

\subsubsection{Risiko Produksi}

Risiko produksi umumnya disebabkan oleh adanya faktor lingkungan (iklim, tanah, temparatur) yang berpengaruh terhadap hasil produksi. Dalam menentukan risiko produksi, langkah pertama yang ditentukan adalah mencari nilai perluang. Nilai peluang diperoleh berdasarkan perbandingan masing-masing kondisi (rendah, sedang, dan tinggi) terhadap produksi salak organik. Hasil yang diperoleh dapat dilihat dalam tabel 3 . 
Tabel 3.

Probabilitas Produksi Salak Organik di Desa Sibetan

\begin{tabular}{cccc}
\hline No. & Kondisi & Probabilitas & $\begin{array}{c}\text { Rata-rata Produksi } \\
(\mathrm{Kg} / \mathrm{Ha})\end{array}$ \\
\hline 1. & Rendah & 0,89 & $1.309,27$ \\
2. & Sedang & 0,09 & 4.480 \\
3. & Tinggi & 0,02 & 12.000 \\
\hline
\end{tabular}

Sumber : Analisis data primer, 2017

Tabel 3 menunjukkan bahwa peluang untuk nilai kondisi rendah adalah 0,89 artinya sebanyak $89 \%$ responden berproduksi rendah, sebanyak sembilan persen responden petani yang berproduksi dengan kriteria sedang, dan peluang petani berproduksi dalam kriteria tinggi yaitu sebanyak dua persen. Setelah dilakukan pengukuran terhadap probabilitas atau peluang dari kejadian yang dilakukan selanjutnya adalah penyelesaian pengambilan keputusan yang mengandung risiko dengan menggunakan ekspektasi produksi. Ekspektasi produksi diperoleh dari jumlah hasil perkalian masing-masing peluang dengan masing-masing produksi salak organik. Adapun nilai ekspektasi produksi salak organik yang diperoleh yaitu $1.808,45 \mathrm{~kg} / \mathrm{ha}$.

Perhitungan tingkat risiko produksi usahatani salak organik dilihat berdasarkan produksi yang dihasilkan oleh petani responden. Adapun nilai varian yang diperoleh adalah 839.013,61, nilai standar deviasi produksi diperoleh senilai menunjukkan sebaran data produksi berada pada interval 915,98, dan hasil perhitungan menunjukkan nilai koefisien variasi yang diperoleh yaitu 0,50 . Nilai koefisen variasi sebesar 0,50 artinya setiap 100 kali panen memiliki peluang gagal panen sebanyak 50 kali dari produksi yang diharapkan.

\subsubsection{Risiko Harga}

Nilai peluang harga diperoleh berdasarkan perbandingan masing-masing kondisi (rendah, sedang, dan tinggi) terhadap harga salak organik. Hasil yang diperoleh dapat dilihat dalam Tabel 4.

Tabel 4.

Probabilitas Harga Salak Organik di Desa Sibetan

\begin{tabular}{cccc}
\hline No. & Kondisi & Probabilitas & $\begin{array}{c}\text { Rata-rata Harga } \\
(\mathrm{Rp} / \mathrm{Kg})\end{array}$ \\
\hline 1. & Rendah & 0,28 & $4.190,48$ \\
2. & Sedang & 0,63 & $5.794,11$ \\
3. & Tinggi & 0,11 & $8.111,11$ \\
\hline
\end{tabular}

Sumber : Analisis data primer, 2017

Berdasarkan tabel 4 menerangkan bahwa sebanyak $28 \%$ responden berproduksi rendah, sebanyak 63\% responden petani yang berproduksi dengan kriteria sedang, 
dan peluang petani berproduksi dalam kriteria tinggi yaitu sebanyak $11 \%$. Setelah dilakukan pengukuran terhadap probabilitas atau peluang dari kejadian yang dilakukan selanjutnya adalah penyelesaian pengambilan keputusan yang mengandung risiko dengan menggunakan ekspektasi harga. Ekspektasi harga diperoleh dari jumlah hasil perkalian masing-masing peluang dengan masing-masing harga salak organik per $\mathrm{kg}$. Adapun nilai ekspektasi harga salak organik yang diperoleh yaitu $\mathrm{Rp} 5.632,05 / \mathrm{kg}$.

Tingkat risiko harga salak organik dilihat berdasarkan nilai varian, simpangan baku, dan koefisien variasi. Adapun nilai varian yang diperoleh adalah 425.074,6, nilai standar deviasi harga diperoleh senilai 651,98 menunjukkan sebaran data harga berada pada interval 651,98, dan hasil perhitungan menunjukkan nilai koefisien variasi yang diperoleh yaitu 0,11 . Nilai koefisen variasi sebesar 0,11 artinya setiap 100 kali panen, petani memiliki peluang kegagalan 11 kali dalam menjual salak organik per-kgnya sesuai harapan. Apabila dilihat dari kriteria KV lebih kecil dari sama dengan 1 mengindikasikan risiko harga masih tergolong rendah.

\subsubsection{Risiko Pendapatan}

Pendapatan merefleksikan nilai yang diperoleh petani dari selisih penerimaan usahatani dengan biaya yang dikeluarkan selama proses usahatani berlangsung. Probabilitas pendapatan dapat diperoleh berdasarkan perbandingan masing-masing kondisi (rendah, sedang, dan tinggi) terhadap pendapatan usahatani salak organik. Hasil yang diperoleh dapat dilihat dalam tabel 5.

Tabel 5.

Probabilitas Pendapatan Usahatani Salak Organik di Desa Sibetan

\begin{tabular}{cccc}
\hline No. & Kondisi & Probabilitas & $\begin{array}{c}\text { Rata-rata Pendapatan } \\
(\mathrm{Rp} / \mathrm{Ha} / \text { panen raya })\end{array}$ \\
\hline 1. & Rendah & 0,93 & $6.166 .156,857$ \\
2. & Sedang & 0,06 & 28.135 .176 \\
3. & Tinggi & 0,02 & 53.889 .500 \\
\hline
\end{tabular}

Sumber : Analisis data primer, 2017

Tabel 5 menjelaskan sebanyak 93\% responden berproduksi rendah, sebanyak $6 \%$ responden petani yang berproduksi dengan kriteria sedang, dan peluang petani berproduksi dalam kriteria tinggi yaitu sebanyak dua persen. Setelah dilakukan pengukuran terhadap probabilitas atau peluang dari kejadian dari pendapatan, yang dilakukan selanjutnya adalah penyelesaian pengambilan keputusan yang mengandung risiko dengan menggunakan ekspektasi Ekspektasi pendapatan diperoleh dari jumlah hasil perkalian masing-masing peluang dengan masing-masing pendapatan usahatani salak organik. Adapun nilai ekspektasi pendapatan salak organik yang diperoleh yaitu Rp 8.500.426,44.

Risiko pendapatan usahatani salak organik dilihat berdasarkan pendapatan yang dihasilkan oleh petani responden. Adapun nilai varian yang diperoleh adalah 
2,26 $\times 10^{13}$, nilai standar deviasi pendapatan diperoleh senilai 4.752.037 menunjukkan sebaran data pendapatan berada pada interval 4.752.037, dan hasil perhitungan menunjukkan nilai koefisien variasi yang diperoleh yaitu 0,55 artinya setiap 100 kali panen memiliki peluang 55 kali keuntungan dalam memperoleh pendapatan sesuai yang diharapkan (expected income). Nilai koefisen variasi sebesar 0,55 artinya Apabila dilihat dari kriteria KV lebih kecil dari sama dengan satu mengindikasikan risiko pendapatan masih tergolong rendah.

\section{Simpulan dan Saran}

\subsection{Simpulan}

Berdasarkan penelitian dan hasil analisis yang telah dilakukan disimpulkan bahwa faktor-faktor yang mempengaruhi pendapatan petani dalam usahatani salak organik di Sibetan adalah luas lahan dan memiliki koefisien positif yang artinya setiap penambahan variabel luas lahan akan meningkatkan perolehan pendapatan usahatani salak organik. Rata-rata biaya usahatani salak organik tahun 2016 sebesar Rp 2.784.050,93, rata-rata penerimaan usahatani salak organik Rp 9.493.215,20 sehingga rata-rata pendapatan yang diterima petani sebesar Rp 6.709.164,27. Risiko usahatani salak organik di Desa Sibetan panen raya tahun 2016 diperoleh hasil KV risiko produksi sebesar $0,50, \mathrm{KV}$ risiko harga sebesar 0,11 , dan $\mathrm{KV}$ risiko pendapatan sebesar 0,55 .

\subsection{Saran}

Penggunaan luas lahan merupakan faktor yang berpengaruh positif terhadap pendapatan usahatani salak organik artinya setiap penambahan penggunaan variabel tersebut akan meningkatkan pendapatan petani responden. Sedangkan faktor lain tidak berpengaruh secara signifikan sehingga, berdasarkan keadaan tersebut diharapkan petani dapat menerapkan kembali kegiatan usahatani yang sesuai standar operasional yang telah ditetapkan agar kuantitas produksi optimal, harga stabil, dan pendapatan yang diperoleh mampu menutupi biaya pengeluaran usahatani.

Perlu pula adanya perhatian khusus oleh pemerintah terkait menentukan stabilitas harga komoditas salak organik dan jaminan terhadap risiko usahatani komoditas tersebut, mengingat ketika panen raya berlangsung harga salak organik rendah dan keadaan tersebut berpengaruh besar terhadap pendapatan petani serta risiko yang harus ditanggung, serta perlu adanya penelitian lanjutan untuk perhitungan analisis risiko usahatani salak organik salam kurun waktu satu tahun.

\section{Ucapan Terimakasih}

Terimakasih peneliti tujukan kepada seluruh pihak yang telah membantu dalam pelaksanaan penelitian hingga karya ilmiah ini bisa dipublikasikan dalam e-jurnal.

\section{Daftar Pustaka}

Darmawi, H. 2004. Manajemen Risiko. Bumi Aksara. Jakarta. 
Dinas Pertanian Tanaman Pangan dan Hortikultura Kabupaten Karangasem. 2016. Perkembangan Produksi Salak Kabupaten Karangasem Tahun 2011-2015. Dinas Pertanian Tanaman Pangan dan Hortikultura Kabupaten Karangasem. Karangasem.

Dewi. 2006. Analisis Profitabilitas dan Pendapatan Usahatani Padi Sawah Menurut Luas Lahan dan Status Kepemilikan Lahan (Studi Kaus Desa Karacak Kecamatan Leuwilang Kabupaten Bogor Jawa Barat). Institut Pertanian Bogor. Bogor. Internet. [Skripsi On-line].

Fauziyah. 2011. Manajemen Risiko pada Usahatani Padi Sebagai Salah Satu Upaya dalam Mewujudkan Ketahanan Pangan Rumah Tangga Petani (Studi Kasus di Desa Telang Kecamatan Kamal). Universitas Trunojoyo. Jawa Timur. Internet. [Skripsi On-line].

Maya, Dede. 2006. Analisis Efisiensi Penggunaan Faktor-faktor Produksi dan Pendapatan Usahatani Salak Bongkok (Kasus di Desa Jambu, Kecamatan Conggeang, Sumedang). Institut Pertanian Bogor.

Salvatore, Dominick. 2003. Managerial Economics dalam Perekonomian Global Edisi Keempat Jilid 2. Erlangga. Jakarta.

Sugiyono. 2007. Metode Penelitian Pendekatan Kuantitatif Kualitatif dan R\&D.. ALFABETA. Bandung.

Soekartawi. 1986. Ilmu Usahatani dan Penelitian Untuk Pengembangan Petani Kecil. Cetakan Ketiga. Universitas Indonesia. Jakarta.

Tenaya,Narka (2015). Ekonometrika. Fakultas Pertanian Universitas Udayana. Denpasar.

Widodo. 2008. Campur Sari Agro Ekonomi. Liberty. Yogyakarta. 